\title{
Exploring Factors Influencing Users' Continuance Intention in Social Networking Sites"
}

\author{
사회네트워킹 사이트 이용자 지속의도에 영향을 미치는 요인에 관한 탐구 \\ 박지홍(Ji-Hong Park)**
}

\begin{abstract}
The success of social networking sites (SNSs) may depend on many factors. Continuance use of SNSs is one of these. Especially, in the Web environment where users can leave one service with a single mouse click, maintaining existing members cost much time and efforts. Without continuance use of SNSs, SNS-based service would not create any value. This study focused on identifying factors influencing users' continuance intention in SNSs. Based on relevant literature review, six influencing factors were initially identified. They were reputation, relational capital, knowledge quality, compatibility, personalization, and satisfaction. Web-based questionnaire survey was conducted and a total of 325 usable responses were collected. Reliability test and two rounds of exploratory factor analyses resulted in identifying five factors. The relationship between the factors and the continuance intention was tested by using multiple regression analyses. The analyses revealed that satisfaction was the most significant factor. Knowledge quality and relational capital also had significant effects while reputation and personalization did not have significant effect on continuance intention. Instead, reputation and personalization showed significance in influencing satisfaction.
\end{abstract}

\section{초 록}

사회네트워킹 사이트(SNS)의 성공은 많은 요소에 의존한다. SNS의 지속적인 이용은 그 중 하나이다. 특히, 이용자가 손쉽게 다른 서비스로 전환할 수 있는 웹 환경에서는 기존 이용자들을 관리하는데 많은 시간과 노력이 소요된다. 이런 점에서, SNS의 지속적인 이용 없이는 SNS를 기반으로 하는 서비스는 가치창출에 실패하게 될 것이다. 본 연구는 SNS 이용자 지속의도에 영향을 미치는 요인들을 발굴하는데 목적이 있다. 초기단계로서, 관련 문헌연구를 통해서 여섯 개의 영향요인을 발굴하였다. 이들은 평판도, 관계적 가치, 지식품 질, 적합성, 개인화, 만족도 이다. 미국 대학 및 대학원생을 대상으로 윕 설문조사를 수행하여 총 325 개의 활용 가능한 데이터를 수집하였다. 신뢰도 검사와 두 차례의 탐험적 요인분석을 수행하여 다섯 개의 최종 영향요인을 발굴하였다. 영향요인들과 지속의도의 관계를 밝히기 위해서 회귀분석을 또한 수행하였다. 만족도가 가장 유효한 요인이었으며 지식품질과 관계적 가치도 유효한 요인이었다. 그러나 평판도와 개인화는 지속의도에 유효한 영향을 미치지 않았다. 대신에 이들의 만족도에 대한 영향은 유효하였다.

키워드: social networking site, continuance, post-adoption use 사회네트워킹사이트, 지속이용, 수용 후 이용

* 이 논문은 2008 한국문헌정보학회/한국정보관리학회/국립중앙도서관 도서관연구소 추계공동학술대회(2008년 11월 7일, 국립중앙도서관)에서 발표한 것을 수정·보완한 것임.

** 연세대학교 문헌정보학과 조교수(jihongpark@yonsei.ac.kr)

- 논문접수일자 : 2008년 11월 17일 - 최초심사일자 : 2008년 11월 19일 - 게재확정일자 : 2008년 12월 1일

- 情報管理學會誌, 25(4)：205-226, 2008. (DOI:10.3743/KOSIM.2008.25.4.205] 


\section{Introduction}

The notion of social networks has been widely discussed these days. Especially, the proliferation of social networking sites (SNSs) such as Cyworld, Facebook, Friendster, and MySpace has led many users to integrate these sites into their daily social life. Despite varied contexts of implementation, common key features were identified across them. SNSs are web-based services that allow users to make their profiles, to list other users as connections, and to mutually visit across the connections (boyd \& Ellison, 2007). The origin of such profile-based network services can be found from SixDegree.com that launched in 1997 (boyd \& Ellison, 2007). It was followed by more sustainable services like Friendster, LinkedIn, MySpace, and Facebook. Some SNSs such as LunarStorm in Sweden and QQ in China focus on domestic users.

The benefit of SNSs is fundamentally based on networking with people. Such connection offers the users the opportunity to foster a self image by constructing their profiles. Through a various source such as visitor comments and counts, the users care about what people think about them. Recent studies from the University of Minnesota reveal that SNSs can benefit K-12 students by helping them develop communication skills, creativity, and decision-making capability (University of Minnesota, 2008). Some librarians adopt SNSs to provide a list of research tools such as Open WorldCat and Google Book Search, then to receive feedback from actual users to develop their information sources (Facebook Librarian, 2007). Other librarians set their profiles in SNSs to get connected to potential library users (e.g., students) to increase a chance to use library services later on. For instance, 55 public libraries in the U.S. have profile pages in the MySpace.com to attract teens (Oleck, 2007). Social networks are also essential in business marketing. They are necessary in every business whether one works in the brick and mortar or on the Web. They enable service providers to increase visibility of a service due to the easy availability of the Internet contents. The providers can increase visibility and create the needed traffic around a service. For instance, Pizza Hut on Cyworld has made over fifty-thousand friendship links with South Koreans (Li \& Bernoff, 2008). Whatever relationships they are, it is critical to let people know that a particular service is available for them.

While such sites are valuable, their success depends on the continuous use of these sites (Brazelton \& Gorry, 2003; Chen, 2007; Parthasarathy \& Bhattacherjee, 1998; Spiller et al., 2007; Tiwana $\&$ Bush, 2005). Without sustaining the use, such sites would lose their memberships and as a result fail to achieve their advantages. Further, recruiting a new member requires about six times higher cost than maintaining an existing members in paid online services, given the cost of marketing and setting up new members (Spiller et al., 2007).

Despite the importance of continuance, little attention has been paid on SNSs in previous studies. 
Relevant studies on virtual communities, expert-sharing networks, and information technology post-adoption have focused on continuance (e.g., Lin, 2007; Tiwana \& Bush, 2005; Thong et al., 2006), however, little or none has been devoted to studying SNSs as they are conceptually distinct from the others. Moreover, even similar topical studies only deal with initial adoption which differs from continuance (e.g., Ridings \& Gefen, 2004). Continuance intention does not exist before the initial use and begins to occur only after the first use. Considering this gap in the prior studies, this study aims at understanding individual users' continuance intention of SNSs by identifying the influencing factors. If these factors can indeed be significant, the results of this study will help online service providers sustain and/or improving their services.

The rest of paper proceeds as follows. Section 1 introduces SNSs. Section 2 explains relevant theory and develops a research framework. Section 3 discusses methods used in this study. Section 4 describes data analysis and results. The final section discusses conclusions and implications.

\section{Social Networking Sites (SNSs)}

Establishing social networks involves connecting people through expanding personal relationships. SNSs have an advantage of increasing network traffic efficiently in a relatively short period of time, which is an attractive model to Internet service providers. The idea of six degrees of separation contributes to their development in that everyone in the world can connect each other within about six steps away from an individual. This idea is also implied in the first of its kind, SixDegree.com that launched in 1997.

The concept of social networking and its phenomenon has existed since 50s. Web-based SNSs has emerged since 2003 and popular sites such as MySpace and Facebook attract many users from all over the world. Accordingly, boyd and Ellison (2007) define SNSs as "web-based services that allow individuals to (1) construct a public or semi-public profile within a bounded system, (2) articulate a list of other users with whom they share a connection, and (3) view and traverse their list of connections and those made by others within the system" (p.2). This definition differentiates SNSs from virtual communities and other similar information and communication technologies in that SNSs focus on developing and maintaining personal profiles by establishing social connections for the purpose of interactions. Further, SNSs focus on existing networks rather than making new relationships with strangers (boyd \& Ellison, 2007; Li \& Bernoff, 2008, p.23).

Generally, SNSs provide such features as tools for personal profile management, bulletin board, social register, and invitation and acceptance mailing. These tools enhance interactions among users when the users visit profile page, post comments, and forward useful information to others. 
This new trend encourages industries to use SNSs for marketing their products (Li \& Bernoff, 2008). Table 1 shows the growth of some popular SNSs.

Cyworld is the most popular SNSs in South Korea maintained by SK Communications Co., Ltd. Starting from a club-centered virtual community in 1999, Cyworld did not gain its popularity until it transformed into individual-profile-based sites in 2001. "Cy" refers to relationships in Korean and its mission is to make good relationships around the world. The relationship of Cyworld called "il-chon" is based on real and existing social relationships made either through online or offline. The members can share personal diary, photos, and music through the profile page which is called "mini-hompi." This profile page is a blog type and used for making individual's life public. The member can change its design and interior by purchasing items such as background images, background music, banners, and fonts. Cyworld is also available in mobile devices, and it is regarded as a successful business model.

Facebook was developed by three Harvard alum- ni in the U.S in 2004. The initial service was limited only to Harvard students and became public in 2006. Members over thirteen years old can converse and share information. In April 2008, it exceeds MySpace in monthly visitor count by reaching 132.1 million members. It is expanding its market share towards Asia. Its strength lies on ease of making connection based on locations and interests. It is also the largest university community in the U.S. including Harvard alumni. Ease of use and convenient interface allows users to make interpersonal networks. Seventy percent of its members came from outside of the U.S. Facebook can also empower library services. Many volunteer librarians so called "Facebook librarians" provide reference services for research help. This social-network-based service allows users to ask librarians in a more interactive, comfortable and convenient way. Facebook librarians often suggest some open research tools such as Open WorldCat and Google Book Search that allow the users to traverse directly from Facebook. After the users solve their information needs, they can rate the

〈Table 1〉 Worldwide Growth of Selected Social Network Sites

\begin{tabular}{c|c|c|c}
\hline \multirow{2}{*}{ Social Network Site } & \multicolumn{3}{|c}{ Total Unique Visitors } \\
\cline { 2 - 4 } & June 2006 & June 2007 & \% Change \\
\hline MySpace & 66,401 & 114,147 & 72 \\
\hline Facebook & 14,083 & 52,167 & 56 \\
\hline Hi5 & 18,098 & 28,174 & 65 \\
\hline Friendster & 14,917 & 24,675 & 78 \\
\hline Orkut & 13,588 & 24,120 & \\
\hline
\end{tabular}

Total Worldwide Home/Work Locations among Internet Users Age 15+

Source: comScore World Metrix (www.comscore.com) 
research tools or suggest new alternatives. Some university libraries already recognize its potential for web-based information services to students.

Friendster has over 5,600 members around the world. Its notable feature is multilingual capability in one domain (www.friendster.com) to support communications among different lingual users. As social networks in Friendster emerge beyond national territories, it is useful to support different languages in one global website. While other SNSs develop new sites whenever they begin a service in a new country, Friendster has sustained one-site policy to enhance multi-cultural communication.

MySpace started its service after getting inspirations from Friendster. When Friendster was getting popular in the U.S. market, the CEO of the LiveUniverse worked together with the employees of Friendster to launch MySpace. The initial intention of this service was to promote Indie(independent) musicians' works, and MySpace became a full-fledged social networking site. Recently, MySpace announced its market expansion to music industry as it has already over 5 million profiles of musicians, actors and actress. When MySpace became popular, many small Web-content development companies used MySpace to attract their users. YouTube, a video sharing website, was one of the successful among these. About 70 percent of YouTube's initial videos were played in MySpace. However, as more and more companies used MySpace, it blocked their commercial use by stating its agreement. This provoked antipathy against MySpace and many users trans- ferred to its competitor, Facebook.

\section{Theoretical Background}

This section discusses theoretical concepts of continuance intention in using SNSs. As individuals' decision-making is critical in SNSs, the unit of analysis is individual rather than organization. Figure 1 shows this study's research framework. Previous literature informs six factors (satisfaction, reputation, relational capital, knowledge quality, compatibility, personalization) as candidates influencing user continuance intention in SNSs.

Continuance is not a new concept in prior research. It has been widely studied under the different names such as post-adoption behavior (e.g., Lippert \& Forman, 2005; Parthasarathy \& Bhattacherjee, 1998; Thong et al., 2006), post-acceptance behavior (e.g., Castaneda et al., 2007), loyalty (e.g., Bhattacherjee, 2001b; Zeithaml et al., 1996), and sustainability (e.g., Lin, 2007; van Deventer \& Snyman, 2004). Similarly, the diffusion of innovation theory suggests five stages of innovation-decision process which are (1) knowledge, (2) persuasion, (3) decision, (4) implementation, and (5) confirmation. At the confirmation stage, individuals reevaluate their initial acceptance of an innovation and decide whether or not continue using an innovation (Rogers, 2003). As discontinuance is defined as "a decision to reject an innovation after having previously adopted it” (Rogers, 2003, p.190), continuance intention is defined here as an individual 
user's intention to continue using a social networking site after having previously adopted it. Initial acceptance and continuance are theoretically distinct as psychological intention to the latter is formed after the former. For instance, technology acceptance model (Davis, 1989) and its subsequences (e.g., Venkatesh \& Davis, 2000) that focus on initial acceptance do not effectively and comprehensively explain how the usage can be continued in post-adoption stage. Perceived usefulness does not explain the most variance in continuance intention (Bhattacherjee, 2001a) while explaining the most in initial acceptance (Davis, 1989; Venkatesh \& Davis, 2000).

Prior related studies have confirmed that satisfaction has the strongest positive influence on the continuance intention. Bhattacherjee (2001a), in developing his expectation-confirmation model, concluded that the continuance intention of information system use is determined by the satisfaction and the perceived usefulness which explains $32 \%$ and
$9 \%$ of the variance respectively. Thong and others (2006) concluded in their expanded study of expectation-confirmation model that satisfaction explains the most $(67.8 \%)$ of continuance intention variance. More specifically, Chen (2007) found that Website use satisfaction is the most significant factor predicting user continuance intention in professional virtual communities. Thus, it is assumed that an individual user's satisfaction with a SNS use positively affects the continuance intention of using the SNS.

Reputation refers to the degree to which an individual user believes him or herself as a significant member among the other members in a SNS (Tiwana \& Bush, 2005). Individual users can increase their reputation in digital environment by contributing contents, revealing their expertise, and being personally identified as new idea generators (Tiwana \& Bush, 2005). As such social activities can enhance reputation, its value lies on a specific social network. Such perceived reputation appears to accelerate the diffusion of an innovation. The

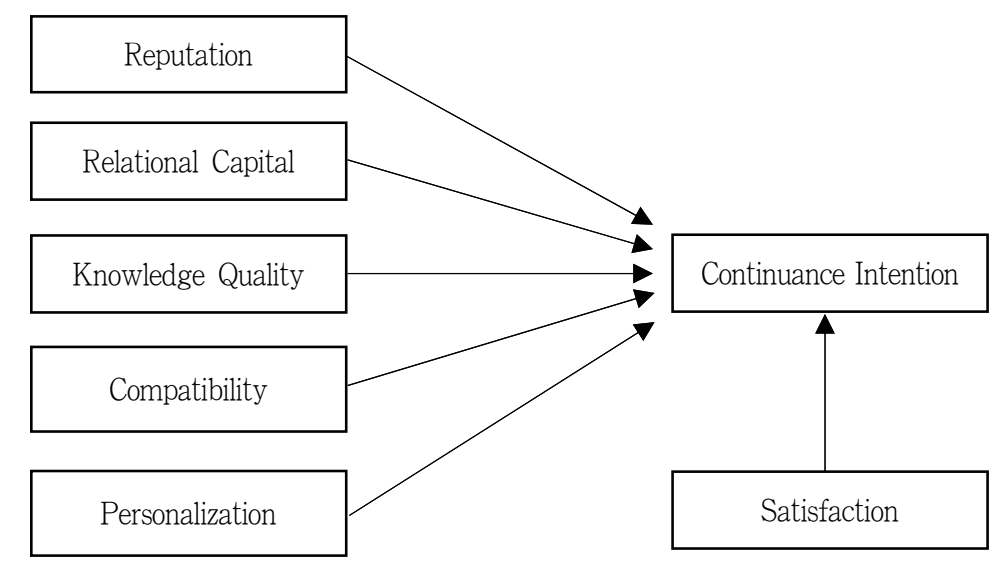

〈Figure 1〉 Research Framework Based on Previous Studies 
diffusion of innovation theory informs reputation as a relative advantage which stimulates the speed of diffusion. Rogers (2003) states "the degree of relative advantage is often expressed as economic profitability, as conveying social prestige, or in other ways" (p.229). There is evidence that reputation leads to continuance intention. Altman and Hernon (1998) suggest that libraries build its service reputation to increase their loyalty. Loyalty is often interchangeably used with continuance intention (e.g., Oh, 2005; Moon \& Lee, 2006). Thus, it is assumed that an individual user's perceived reputation positively affects the continuance intention of using a SNS.

Relational capital is conceptualized as the degree of trust and respect emerging from close interpersonal relationship with other peer members in a social networking site (Tiwana \& Bush, 2005). Several types of relationships can exist in a social network and the strength of tie varies according to the type of relationships. Some relationships would be based on acquaintance while others would be on kinship. The strength depends on trust of its members and vice versa (Buskens, 2002). Unlike traditional monetary asset, it is not reduced by use but it is reduced by non-use. Similarly, social capital refers to "investment in social relations with expected returns and the marketplace" (Lin, 2001, p.19). Social capital focuses on expected value embedded in social relations while the value does not limit to trust. Social capital has broader dimension than relational capital.

It is well known that trust facilitates knowledge transfer among the members of distributed communities (Chen, 2007; Piccoli \& Ives, 2003; Wenger et al., 2002). In other words, the stronger relationship a tie holds, the more knowledge transfers occur between the members. By virtue of these, relational capital influences the degree of knowledge sharing. However, it takes relatively a long period of time to build trust so that members of a SNS may not easily switch to an alternative SNS if they maintain a certain level of relational capital. Chen's (2007) study also tested that post-usage social interaction has a significant influence on the continuance intention of using a virtual community. Thus, it is assumed that an individual user's relational capital positively affects the continuance intention of using a SNS.

Knowledge quality refers to the degree to which an individual user believes that a SNS contains high quality contents. It originates from the concept of information quality which refers to "the quality of information that the system produces, primarily in the form of reports" (DeLone \& McLean, 2003, p.64). Information quality is a major factor influencing an information system use (DeLone \& McLean, 2003). In the same line, Chen (2007) proposes the concept of knowledge quality while discussing continuance intentions in professional virtual communities. Similarly, knowledge quality rather than information quality is used here because most contents in SNSs are based on a certain community and the posted knowledge is justified only within the community. In other words, knowledge posted in SNSs is situated and meaningful in a 
certain social context.

Given the fact that SNSs allow users to contribute to content development by posting new knowledge, SNSs enable peer users to learn new knowledge and to improve their work performance. Such knowledge-driven benefit may encourage users to evaluate the quality of knowledge and the evaluation leads them to determine whether or not they continue to use the SNS. Thus, it is assumed that an individual user's knowledge quality positively affects the continuance intention of using a SNS.

Compatibility refers to the degree to which an individual user believes that a SNS use is consistent with the user's values, experiences, and needs (Parthasarathy \& Bhattacherjee, 1998). It originates from the diffusion of innovation theory that informs compatibility influences post-adoption use of an innovation (Rogers, 2003). Parthasarathy and Bhattacherjee (1998) found that compatibility is a significant factor influencing the continuance use of online services by comparing continuing adopters $(n=69)$ and discontinuers $(n=76)$. Thus, it is assumed that an individual user's compatibility positively affects the continuance intention of using a SNS.

Personalization is defined as "customizing an information system to an individual user's preferences" in the study of expertise-sharing networks (Tiwana \& Bush, 2005, p.90). Similar definition can be found in digital library personalization. It is defined as "the way in which information and services can be tailored to match the unique and specific needs of an individual or a community"
(Frias-Martinez et al., 2007, p.237). When considering personalization in general, both definitions stress tailoring to user preferences. In SNSs, users manually customize their profiles by creating usernames, menus, or avatars. Personalization in SNS is closely related to modifying user profiles to fit their preferences. Thus, it refers to the degree to which an individual user believes that he or she has invested time and effort in customizing a SNS to the user's preferences.

Widespread use of SNSs drives the users to expect more sophisticated information as the volume of information and the type of functions increase. A buddy list, normally an integral part of any SNS, can filter peer contributions based on the user preferences. By deriving such additional value, personalization is regarded as improving user satisfaction (Frias-Martinez et al., 2007; Marchionini et al., 1998). As customizing profile allows users to utilize SNS in a more convenient and satisfying way, it is assumed that an individual user's personalization positively affects the continuance intention of using a SNS.

\section{Methodology}

This section describes the procedure of field survey conducted to identify factors influencing the continuance intention in SNSs. It is organized as two parts: instrument development and data collection. 


\subsection{Instrument Development}

Seven constructs were measured in this study and all the scales were drawn from empirically-tested prior studies. A number of research articles in the information science field and information systems field dealing with the continuance intentions in post-adoption stage were reviewed. The items were worded in reference to a "social networking site." Satisfaction items were based on seven-point scales that are semantically different. Personalization items were based on seven-point scales ranging from "a huge amount" via "some" to "none." All remaining item scale used seven-point Likert scales ranging from "strongly disagree" via "neutral" to "strongly agree." Items used for the constructs are shown in Table 2. In addition, questions asking SNS usage, demographic information, and any open-ended comments were included in the survey questionnaire

Reputation and relational capital were measured using Tiwana and Bush's (2005) five items which were developed and validated from mixed methodological study. Their study used qualitative observation data obtained during four years and quantitative data obtained from 120 questionnaire survey respondents. Their study originally designed to measure users' perceived reputation in expertise-sharing networks which is conceptually similar but not same as SNSs.

Knowledge quality was measured by the items complementarily adapted from Chen (2007) and DeLone and McLean (2003). DeLone and McLean's items were originally set to measure information quality by using the five items: accuracy, timeliness, completeness, relevance, and consistency (p.15). These items were then revised by using Chen's statements to make more compatible with social networking contexts.

Compatibility was measured by multiple items taken from Parthasarathy and Bhattacherjee (1998). The items were worded to fit respondents' perceptions on SNSs.

Personalization was measured by Tiwana and Bush's (2005) five items that used the amount of time and effort that a user invested in managing a user name, creating and managing a profile, choosing and managing a user icon, and customizing preferences. Unlike other scales, personalization was scaled by seven-point as "a huge amount", "very much", "much", "some", "little", "very little", and "none."

Satisfaction and continuance intention were measured using Bhattacherjee's (2001a) scales from the post-adoption literature, originally designed to assess user's satisfaction and continuance intention with an online banking service. Satisfaction scale in this study reflected the degree of respondents' satisfaction by seven-point scales anchored between four semantically-different pairs. For instance of "very dissatisfied / very satisfied", the seven-point scale as "very dissatisfied", "dissatisfied", "somewhat dissatisfied", "neutral", "somewhat satisfied", "satisfied", and "very satisfied" was used. This scale was also worded to capture post-usage satisfaction rather than pre-usage satisfaction. Continuance 
$\langle$ Table 2〉 Operationalization of Constructs

\begin{tabular}{|c|c|c|c|}
\hline Construct & Item & Statement & Source \\
\hline \multirow{5}{*}{ Reputation } & R1 & Other members consider my posts valuable. & \multirow{5}{*}{$\begin{array}{l}\text { Tiwana and Bush } \\
\quad(2005)\end{array}$} \\
\hline & $\mathrm{R} 2$ & Other members consider my posts useful. & \\
\hline & R3 & Other members consider my posts helpful. & \\
\hline & $\mathrm{R} 4$ & Other members consider my posts important. & \\
\hline & R5 & I enjoy a reputation for posting a lot. & \\
\hline \multirow{5}{*}{$\begin{array}{l}\text { Relational } \\
\text { Capital }\end{array}$} & $\mathrm{RC1}$ & Overall, my relationship with other members is personally friendly. & \multirow{5}{*}{$\begin{array}{l}\text { Tiwana and Bush } \\
\quad(2005)\end{array}$} \\
\hline & $\mathrm{RC} 2$ & Overall, my relationship with other members is mutually trusting. & \\
\hline & RC3 & Overall, my relationship with other members is mutually respectful. & \\
\hline & $\mathrm{RC} 4$ & Overall, my relationship with other members is highly give-and-take. & \\
\hline & RC5 & $\begin{array}{l}\text { Overall, my relationship with other members is close and, personally } \\
\text { interactive. }\end{array}$ & \\
\hline \multirow{5}{*}{$\begin{array}{l}\text { Knowledge } \\
\text { Quality }\end{array}$} & KQ1 & $\begin{array}{l}\text { The knowledge shared by members in this social networking site is } \\
\text { accurate. }\end{array}$ & \multirow{5}{*}{$\begin{array}{c}\text { Chen (2007); } \\
\text { DeLone and } \\
\text { McLean } \\
\text { (2003) }\end{array}$} \\
\hline & KQ2 & $\begin{array}{l}\text { The knowledge shared by members in this social networking site is } \\
\text { timeliness. }\end{array}$ & \\
\hline & KQ3 & $\begin{array}{l}\text { The knowledge shared by members in this social networking site is } \\
\text { complete. }\end{array}$ & \\
\hline & KQ4 & $\begin{array}{l}\text { The knowledge shared by members in this social networking site is } \\
\text { relevant. }\end{array}$ & \\
\hline & KQ5 & $\begin{array}{l}\text { The knowledge shared by members in this social networking site is } \\
\text { reliable. }\end{array}$ & \\
\hline \multirow{4}{*}{ Compatibility } & $\mathrm{C} 1$ & I feel this social networking site fits well with my knowledge base. & \multirow{4}{*}{$\begin{array}{c}\text { Parthasarathy and } \\
\text { Bhattacherjee } \\
\text { (1998) }\end{array}$} \\
\hline & $\mathrm{C} 2$ & I feel this social networking site is easy for me to adjust to. & \\
\hline & $\mathrm{C} 3$ & I feel this social networking site fits my lifestyle very well. & \\
\hline & $\mathrm{C} 4$ & I feel this social networking site fits my daily routine well. & \\
\hline \multirow{6}{*}{ Personalization } & \multicolumn{2}{|r|}{$\begin{array}{l}\text { How much time and effort have you invested in the following activities on } \\
\text { this social networking site? }\end{array}$} & \multirow{6}{*}{$\begin{array}{l}\text { Tiwana and Bush } \\
\quad(2005)\end{array}$} \\
\hline & P1 & Managing my username. & \\
\hline & P2 & Creating and managing my personal profile. & \\
\hline & P3 & Creating a personalized menu. & \\
\hline & P4 & Choosing and managing a user icon (or avatar). & \\
\hline & P5 & Customizing my preferences. & \\
\hline \multirow{5}{*}{ Satisfaction } & $\begin{array}{l}\text { How } \\
\text { use? }\end{array}$ & lo you feel about your overall experience of the social networking site & \multirow{5}{*}{$\begin{array}{l}\text { Bhattacherjee } \\
\quad(2001 a)\end{array}$} \\
\hline & $\mathrm{S} 1$ & Very dissatisfied / Very Satisfied & \\
\hline & S2 & Very displeased / Very pleased & \\
\hline & S3 & Very frustrated / Very contented & \\
\hline & S4 & Absolutely terrible / Absolutely delighted & \\
\hline \multirow{3}{*}{$\begin{array}{l}\text { Continuance } \\
\text { Intention }\end{array}$} & CI1 & $\begin{array}{l}\text { I intend to continue using this social networking site, rather than } \\
\text { discontinuing its use. }\end{array}$ & \multirow{3}{*}{$\begin{array}{l}\text { Bhattacherjee } \\
\quad(2001 \mathrm{a})\end{array}$} \\
\hline & $\mathrm{CI} 2$ & $\begin{array}{l}\text { My intentions are to continue using this social networking site, rather } \\
\text { than using any alternative social networking site. }\end{array}$ & \\
\hline & $\mathrm{CI} 3$ & $\begin{array}{l}\text { If I could, I would discontinue my use of this social networking site. } \\
\text { (reverse coded) }\end{array}$ & \\
\hline
\end{tabular}


intention was measured using three items. The first two items captured respondents' intention to continue using a specific SNS as opposed to discontinuing it or using any alternative SNS. The third item measured respondents' overall discontinuance intention. It was worded reversely to avoid potential common method bias (Podsakoff et al., 2003).

\subsection{Data Collection}

This study used a Web-based field survey of SNS users. Survey respondents were undergraduate and graduate students from two universities (Syracuse University and University of North Carolina at Chapel Hill) in the United States. The questionnaire was designed to allow respondents to choose a SNS which they have used before. Respondents who have no prior experience or have already stopped using a SNS were eliminated as this study focuses on continuous use of SNSs. Data were collected between Sept 3, 2008 and Sept 22, 2008 by using the Survey Monkey (http://www.surveymonkey.com/), a Web-based survey application. It was set to automatically prevent the same respondents from answering the questionnaire more than once.

The email addresses of the sample were obtained from the student directory of the two universities. A total of 3,000 students were selected by alphabetical order of last name from the directory. Each student received an invitation email appealing for their participation in a survey of social networking site. The invitation message included the study goal, a hyperlink to a Web-based survey questionnaire, anonymity and privacy policy, and opt-out option. The opt-out option message was: "If you do not wish to receive further emails from us, please click the link below, and you will be automatically removed from our mailing list. [RemoveLink]."

Web-based surveys have several advantages over traditional mail-based surveys. They include ease of administration, fast data collection and analysis, relatively low cost, anonymity, and avoidance of interview bias. However, it has such limitations as that sample is limited to the Internet users and questionnaire requires highly structured with predominantly closed-end questions. SNS users are primarily the Internet users and all the questions of this study were adapted from the previously validated literatures (see Table 2).

This study collected a total of 325 usable responses. Out of 361 received responses, 36 were unusable missing data. A power analysis was conducted to assess generalizability coined by the sample size. Cohen (1988) suggested a small effect size as 0.02 , a medium as 0.15 , and a large as 0.35 in multiple regression analysis. It means each of the effect size explains $2 \%, 15 \%$, and $35 \%$ of variance on dependent variable respectively. With six independent variable in this study, adequate sample size was calculated by using G*Power application developed and suggested by Erdfelder and others (1996). The result suggests that at least 146 samples are necessary for the medium effect size. Considering this study's sample size $(n=325)$, 
the condition of medium effect was met.

Table 3 shows the respondents' demographic profiles. Most of respondents' (90.5\%) ages were under 30 years, with a distribution of $35.4 \%$ in their $10 \mathrm{~s}, 55.1 \%$ in 20 s. Female respondents consisted of a majority (62.5\%). A majority of respondents $(63 \%)$ are currently undergraduate students and the rest $(34.1 \%)$ are graduate students. Respondents' enrolled institutions were Syracuse University (48\%) and University of North Carolina at Chapel Hill $(52 \%)$. The largest group of respondents identified their academic major as liberal arts (13.8\%). Management (9.8\%) followed as the second. The remaining groups' distribution ranged from $0.3 \%$ to $7.7 \%$. Other majors $(1.5 \%)$ were anthropology, creative writing, and international studies.

Reliability (internal consistency) of each variable was assessed by using Cronbach's alpha. Cronbach's alpha is a widely used statistic to compute internal consistency of multiple scale items by applying the correlations between the items in a split-half method. Hence, Cronbach's alpha value increases as the correlations between the items increase, and it shows how well a set of scale items reflect a latent variable. According to Nunnully (1967), a minimum value of 0.6 is enough for early stages of investigation. Given that all the Cronbach's alphas exceeds 0.6 (Table 4) and this study has exploratory nature, this study's items seem to have enough reliability.

〈Table 3〉 Descriptive Statistics of the Respondents' Demographical Characteristics

\begin{tabular}{|c|c|c|c|}
\hline Measure & Items & Frequency & Percent \\
\hline $\begin{array}{c}\text { Age } \\
(\mathrm{n}=319)\end{array}$ & $\begin{array}{l}15-19 \\
20-24 \\
25-29 \\
30-34 \\
35-39 \\
40-44 \\
45 \text { or older } \\
\text { (Missing) }\end{array}$ & $\begin{array}{r}115 \\
131 \\
48 \\
18 \\
2 \\
4 \\
1 \\
6\end{array}$ & $\begin{array}{r}35.4 \\
40.3 \\
14.8 \\
5.5 \\
0.6 \\
1.2 \\
0.3 \\
1.8\end{array}$ \\
\hline $\begin{array}{l}\text { Gender } \\
(\mathrm{n}=318)\end{array}$ & $\begin{array}{l}\text { Male } \\
\text { Female } \\
\text { (Missing) }\end{array}$ & $\begin{array}{r}115 \\
203 \\
7 \\
\end{array}$ & $\begin{array}{r}35.4 \\
62.5 \\
2.2 \\
\end{array}$ \\
\hline $\begin{array}{l}\text { Current } \\
\text { educational level } \\
\quad(n=316)\end{array}$ & $\begin{array}{l}\text { Freshman } \\
\text { Sophomore } \\
\text { Junior } \\
\text { Senior } \\
\text { Master's student } \\
\text { Doctorate student (including Medical Doctor) } \\
\text { Other } \\
\text { (Missing) }\end{array}$ & $\begin{array}{r}92 \\
31 \\
28 \\
54 \\
55 \\
56 \\
0 \\
9\end{array}$ & $\begin{array}{r}28.3 \\
9.5 \\
8.6 \\
16.6 \\
16.9 \\
17.2 \\
0 \\
2.8 \\
\end{array}$ \\
\hline $\begin{array}{l}\text { Current affiliated } \\
\text { institution } \\
(\mathrm{n}=325)\end{array}$ & $\begin{array}{l}\text { Syracuse University } \\
\text { University of North Carolina at Chapel Hill }\end{array}$ & $\begin{array}{l}156 \\
169\end{array}$ & $\begin{array}{l}48 \\
52\end{array}$ \\
\hline
\end{tabular}




\begin{tabular}{|c|c|c|c|}
\hline $\begin{array}{l}\text { Academic major } \\
\quad(\mathrm{n}=322)\end{array}$ & $\begin{array}{l}\text { Liberal Arts } \\
\text { Management } \\
\text { Education } \\
\text { Communication } \\
\text { Computer Science } \\
\text { Sciences } \\
\text { Sociology } \\
\text { Engineering } \\
\text { Political Science } \\
\text { Human Services Health Professions } \\
\text { Visual \& Performing Arts } \\
\text { Economics } \\
\text { Environmental Science } \\
\text { Information Studies / Library and Information Science } \\
\text { Design } \\
\text { Law } \\
\text { Psychology } \\
\text { Public Administration } \\
\text { Other } \\
\text { Architecture } \\
\text { Music } \\
\text { (Missing) }\end{array}$ & $\begin{array}{r}45 \\
32 \\
25 \\
24 \\
23 \\
22 \\
18 \\
16 \\
16 \\
15 \\
13 \\
12 \\
10 \\
10 \\
9 \\
9 \\
7 \\
7 \\
5 \\
3 \\
1 \\
3\end{array}$ & $\begin{array}{r}13.8 \\
9.8 \\
7.7 \\
7.4 \\
7.1 \\
6.8 \\
5.5 \\
4.9 \\
4.9 \\
4.6 \\
4.0 \\
3.7 \\
3.1 \\
3.1 \\
2.8 \\
2.8 \\
2.2 \\
2.2 \\
1.5 \\
0.9 \\
0.3 \\
0.9\end{array}$ \\
\hline
\end{tabular}

〈Table 4〉 Reliability of Variables

\begin{tabular}{l|c|c}
\hline \multicolumn{1}{c|}{ Variable Name } & \# of items & Cronbach's alpha \\
\hline Reputation (R) & 5 & 0.893 \\
\hline Relational Capital (RC) & 5 & 0.788 \\
\hline Knowledge Quality (KQ) & 5 & 0.862 \\
\hline Compatibility (C) & 4 & 0.858 \\
\hline Personalization (P) & 5 & 0.861 \\
\hline Satisfaction (S) & 4 & 0.906 \\
\hline Continuance Intention (CI) & 3 & 0.756 \\
\hline
\end{tabular}

\section{Data Analysis and Results}

\subsection{Description of Social Networking Site Use}

The frequencies and percentages of the respondents' use of SNSs are shown in Table 5.
It describes currently most frequently-used SNS, the number of times of visit per week, amount of spending time per log-in, main tasks, and existence of profile page.

The relatively higher usage rate $(86.2 \%)$ of Facebook reflected that Facebook was the most popular SNS among university students considering 
〈Table 5〉 Descriptive Statistics of the Respondents' Social Networking Site Use

\begin{tabular}{|c|c|c|c|}
\hline \multicolumn{2}{|r|}{ Characteristics } & Frequency & Percent \\
\hline $\begin{array}{l}\text { Social network site currently } \\
\text { being used most frequently }\end{array}$ & $\begin{array}{l}\text { Facebook } \\
\text { MySpace } \\
\text { Cyworld } \\
\text { Orkut } \\
\text { QQ } \\
\text { Hi5 } \\
\text { Friendster } \\
\text { Other }\end{array}$ & $\begin{array}{r}280 \\
16 \\
14 \\
8 \\
4 \\
2 \\
1 \\
0\end{array}$ & $\begin{array}{r}86.2 \\
4.9 \\
4.3 \\
2.5 \\
1.2 \\
0.6 \\
0.3 \\
0\end{array}$ \\
\hline $\begin{array}{c}\text { Number of times each week } \\
\text { the respondents visit social } \\
\text { networking sites }\end{array}$ & $\begin{array}{l}\text { Less than one } \\
\text { One } \\
\text { Two } \\
\text { Three } \\
\text { Four } \\
\text { Five } \\
\text { More than five }\end{array}$ & $\begin{array}{r}18 \\
11 \\
15 \\
23 \\
18 \\
31 \\
209 \\
\end{array}$ & $\begin{array}{r}5.5 \\
3.4 \\
4.6 \\
7.1 \\
5.5 \\
9.5 \\
64.3 \\
\end{array}$ \\
\hline $\begin{array}{l}\text { Amount of time the } \\
\text { respondents spend online } \\
\text { each time they log on }\end{array}$ & $\begin{array}{l}\text { Less than } 15 \text { minutes } \\
15-20 \text { minutes } \\
30-60 \text { minutes } \\
1-2 \text { hours } \\
\text { Over } 2 \text { hours }\end{array}$ & $\begin{array}{r}136 \\
112 \\
54 \\
12 \\
11\end{array}$ & $\begin{array}{r}41.8 \\
34.5 \\
16.6 \\
3.7 \\
3.4\end{array}$ \\
\hline Task & $\begin{array}{l}\text { Visit other users' profiles } \\
\text { Leave comments on other users' profile pages } \\
\text { Manage my profile(s) } \\
\text { Visit communities (clubs) } \\
\text { Upload or download file(s) }\end{array}$ & $\begin{array}{r}270 \\
227 \\
154 \\
51 \\
47\end{array}$ & $\begin{array}{r}36.0 \\
30.3 \\
20.6 \\
6.8 \\
6.3\end{array}$ \\
\hline Profile page & $\begin{array}{l}\text { Yes } \\
\text { No } \\
\text { (Missing) }\end{array}$ & $\begin{array}{r}317 \\
6 \\
2\end{array}$ & $\begin{array}{r}97.5 \\
1.8 \\
0.6\end{array}$ \\
\hline
\end{tabular}

MySpace, a competitor of Facebook, accounted for only $4.9 \%$. Other SNSs accounted for ranges from $0.3 \%$ to $4.3 \%$. Most respondents used a SNS more than five times per week (64.3\%), and they spent online less than twenty minutes $(76.3 \%)$ each time they logged on. Only small distribution (7.1\%) stayed online more than one hour. The frequencies in the task category describe the respondents' main tasks when they visited a SNS. A majority of tasks (86.9\%) were visiting other users' profiles, leaving comments on other users' profile pages, and managing my profile. The rest of tasks, visiting communities and uploading or downloading files accounted for only $13.1 \%$. These distributions reflected that SNS users were mainly concerned with building and maintaining social relationships with others rather than achieving or distributing information through communities. Most of the respondents $(97.5 \%)$ also had their own profile page. 


\subsection{Exploratory Factor Analysis}

Two rounds of principal component analyses with varimax rotation were performed. The first round analysis (see Appendix I) shows six factors with eigenvalues greater than 1.0 were extracted and they explained $68.8 \%$ of the total variance. Minimum necessary factor loadings were set to 0.5 by following Hair and others (1992). While most loadings satisfied this criterion, there were four exceptions: $\mathrm{C} 1$ in factor1, $\mathrm{R} 5$ in factor2, $\mathrm{RC} 4$ in factor6, and RC5 in factor6.

Excluding the four exceptions, the second round factor analysis were performed (see Appendix II). Most loadings satisfied Hair and others' (1992) criteria except one. Satisfaction variable and compatibility variable were loaded in same factor. It seems due to the similarity between the items of both variables. For instance, one item in compatibility variable, "I feel this social networking site fit my lifestyle very well" could play as a satisfaction scale. For this reason, this study collapsed these two into one factor, satisfaction. Thus, the new satisfaction variable has seven items: S1, S2, $\mathrm{S} 3, \mathrm{~S} 4, \mathrm{C} 2, \mathrm{C} 3$, and $\mathrm{C} 4$. In the second round, five factors had eigenvalues greater than 1.0 and explained $69.6 \%$ of the total variance, which was higher than the first round variance.

\subsection{Multiple Regression}

Five factors (reputation, personalization, knowledge quality, relational capital, and satisfaction) were identified the exploratory factor analysis in the previous section. Satisfaction, however, were often suggested as the strongest influencing factors for continuance intentions among others (Bhattacherjee, 2001a; Chen, 2007; and Thong et al., 2006). This aspect leaded this study to an exploratory test of the relationship between satisfaction and other factors to see existence of further relationships.

Multiple regression analyses were performed in two steps as shown in Table 6. The first step was to examine the relationship between four independent variables (reputation, personalization, knowledge quality, and relational capital) and a dependent variable (satisfaction). Knowledge quality and relational capital had significant influences on satisfaction. Unlike the expectation of this study, reputation and personalization did not significantly affect the degree of satisfaction. These relationships appeared also in the second step of the regression test. With the dependent variable as continuance intention, five independent variables (reputation, personalization, knowledge quality, relational capital, and satisfaction) were tested for their significances. Satisfaction, knowledge quality, and relational capital were significant in influencing the continuous use of SNSs while reputation and personalization were not.

Figure 2 shows a graphical representation of the relationship between independent variables and dependent variables. Continuance intention was influenced by satisfaction with the largest variance (60.6\%). Knowledge quality and relational capital explained $17.3 \%$ and $15 \%$ respectively of total 
$\langle$ Table 6〉 Results of Regression Tests

\begin{tabular}{l|l|l|c|c|c}
\hline & Dependent Variable & Independent Variables & Beta $(\beta)$ & $\mathrm{t}$ & Sig. \\
\hline \multirow{4}{*}{ Model 1 } & \multirow{3}{*}{ Satisfaction (S) } & Reputation (R) & 0.107 & 2.004 & $0.046^{*}$ \\
\cline { 3 - 6 } & & Personalization (P) & 0.138 & 2.572 & $0.011^{*}$ \\
\cline { 3 - 6 } & & Knowledge Quality (KQ) & 0.173 & 3.231 & $0.001^{* *}$ \\
\cline { 3 - 6 } & Relational Capital (RC) & 0.146 & 2.719 & $0.007^{* *}$ \\
\hline \multirow{4}{*}{ Model 2 } & Continuance Intention & Reputation (R) & 0.004 & 0.099 & 0.922 \\
\cline { 3 - 6 } & & Personalization (P) & 0.016 & 0.371 & 0.711 \\
\cline { 3 - 6 } & Knowledge Quality (KQ) & 0.173 & 4.064 & $0.000^{* *}$ \\
\cline { 3 - 6 } & & Relational Capital (RC) & 0.150 & 3.525 & $0.000^{* *}$ \\
\cline { 3 - 6 } & & Satisfaction (S) & 0.606 & 14.199 & $0.000^{* *}$ \\
\hline
\end{tabular}

Note: ** $\mathrm{p}\left\langle 0.01 ; * \mathrm{p}\left\langle 0.05 ;\right.\right.$ Model1: $R=0.286 ; R^{2}=0.082 ;$ Adjusted $R^{2}=0.070$; Model2: $R=0.648$; $R^{2}=0.420$; Adjusted $R^{2}=0.411$; Dependent Variable: Satisfaction $(\mathrm{S})$, Continuance Intention (CI).

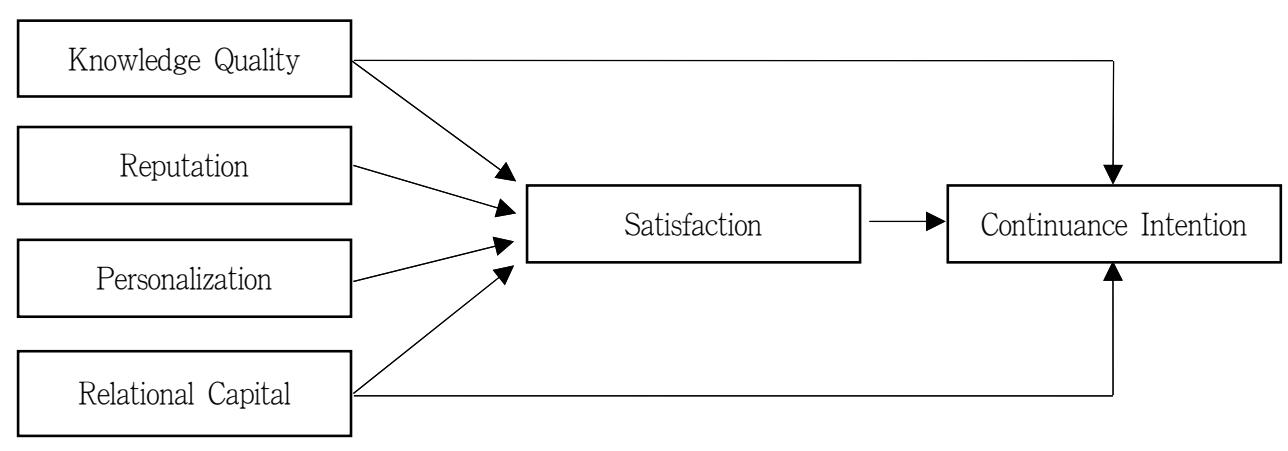

〈Figure 2〉 Factors Influencing the Continuance Intention in Social Networking Sites

variance in influencing continuance intention. Whereas, satisfaction was influenced by four factors which were knowledge quality, reputation, personalization, and relational capital. Knowledge quality and relational capital had stronger influence than reputation and personalization. Reputation and personalization did not have direct influence on continuance intention. These two affected continuance intention only through satisfaction.

\section{Discussions}

The success of SNSs may depend on many factors. These factors include economic and governmental policy, culture, marketing strategies or many others. Continuance was identified as one of key success factors in sustaining an information service. Especially, in the Web environment where users can leave one service with a single mouse click, maintaining existing members cost much time and efforts. SNS use is no exception. Without 
continuance use of SNSs, SNS-based service would not create any value based on Web traffics and user connections.

There are several popular SNSs. MySpace, Facebook, Hi5, Friendster, and recently Orkut are these. SNSs are conceptually distinct from other similar service such as virtual community. They focus on social connections as well as information that can be obtained from these relationships. Common characteristics of SNSs include having a profile, a list of other members' profile page, and traversing their list of profiles. These conceptual distinctions led the researcher to focus on the continuance of SNSs.

This study focused on identifying factors influencing users' continuance intention in SNSs. Based on relevant literature review, six influencing factors were initially identified. They were reputation, relational capital, knowledge quality, compatibility, personalization, and satisfaction. Web-based questionnaire survey was conducted and a total of 325 usable responses were collected. Reliability test and two rounds of principal component analyses resulted in identifying five factors. These factors were reputation, relational capital, knowledge quality, personalization, and satisfaction. Compatibility was combined with satisfaction to form a new satisfaction.

The relationship between the factors and the continuance intention was tested by using multiple regression analyses. The analyses revealed that satisfaction was the most significant factor and reputation and personalization affected the continuance only through the satisfaction. Two other factors, knowledge quality and relational capital influenced the continuance intention both directly and indirectly through the satisfaction. It reflects that maintaining quality contents and quality social relations are critical factors for the continuance of SNSs. The insignificance of personalization on the continuance intention implies that users feel annoyed at continuous profile updates. Personalization is one of representative SNS functions and this technological feature was believed to provide more flexibility. Personalization in SNSs however might become a burden to some users who should spend some amount of time and effort in managing and updating their profiles. Unlike personalization in other information system, SNS personalization demands users to update their profiles frequently when they realize other members show off their updated profiles. Such social-relationship-based and competition-like interactions could urge the users toward frequent updates of their profiles, which might psychologically bother the users. The insignificance of reputation, in other hands, implies that users do not regard other members respect as important as other factors when they decide to continuously use SNSs. However, the significance of reputation on satisfaction implies that users feel some amount of satisfaction from other members respect.

This study has both research and practical implications. It contributed to post-adoption studies by expanding its dimension towards new social media, SNSs. It also provided a base framework for evaluating SNSs although a series of further 
confirmatory studies are necessary. For instance, an evaluator can put more priority on knowledge quality and social capital than other factors. It may also be used as a framework for promoting SNSs by focusing on the continuous use. Knowing significant influencing factors may allow more effective and efficient way of SNSs promotion within a limited time and budget.

This study has however a few limitations. Web-based questionnaire cannot guarantee the val- idity of the data. Self-reported and cross-sectional data may have some bias. Most users responded Facebook as their mostly-used SNS and all the responses were based on each user's beliefs on the SNS. Thus, analyses of more diverse SNSs are necessary in the future. Lastly, further confirmatory studies are necessary as reputation and personalization provided unexpected results. Relationship between relational capital and personalization would be a case.

\section{References}

Altman, E., \& P. Hernon. 1998. "Service quality and customer satisfaction do matter." American Libraries, 29(7), 53-54.

Bhattacherjee, A. 2001a. "Understanding information systems continuance: An expectationconfirmation model.” MIS Quarterly, 25(3), 351-370.

Bhattacherjee, A. 2001b. "An empirical analysis of the antecedents of electronic commerce service continuance.” Decision Support Systems, 32, 201-214.

boyd, D. M., \& N. B. Ellison. 2007. "Social network sites: Definition, history, and scholarship." Journal of Computer-Mediated Communication, 13(1), article 11. Retrieved from. $<$ http://jcmc.indiana.edu/vol13/issue1/boy d.ellison.html>.

Brazelton, J., \& G. Gorry. 2003. "Creating a knowledge-sharing community: If you build it, will they come?" Communications of the $A C M, 46(2), 23-25$.

Buskens, V. 2002. Social networks and trust. Boston, MA: Kluwer Academic Publishers.

Castaneda, J. A., F. Munoz-Leiva, \& T. Luque. 2007. "Web Acceptance Model (WAM): Moderating effects of user experience." Information \& Management, 44(4), 384-396.

Chen, I.Y.L. 2007. “The factors influencing members' continuance intentions in professional virtual communities-A longitudinal study." Journal of Information Science, 33(4), 451-467.

Cohen, J. 1988. Statistical power analysis for the behavior sciences $\left(2^{\text {nd }}\right.$ Ed.). Hillsdale, $\mathrm{NJ}$ : Lawrence Erlbaum.

Davis, F. D. 1989. "Perceived usefulness, perceived ease of use, and user acceptance of infor- 
mation technology." MIS Quarterly, 13(3), 319-340.

DeLone, W. H., \& E. R. McLean. 2003. "The DeLone and McLean model of information systems success: a ten-year update." Journal of Management Information Systems, 19(4), 9-30.

Erdfelder, E., F. Faul, \& A. Buchner. 1996. "GPOWER: A general power analysis program." Behavior Research Methods, Instruments, \& Computers, 28, 1-11.

Facebook App (Facebook) Librarian: Books, Scholarly Resources, Facts+Stuff, Ask A Librarian. 2007, July 3. Retrieved from. $<\mathrm{http}$ //onlinesocialnetworks.blogspot.com /2007/07/facebook-app-facebook-librarian -books.html>.

Frias-Martinez, E., S. Y. Chen, \& X. Liu. 2007. "Automatic cognitive style identification of digital library users for personalization." Journal of the American Society for Information Science and Technology, 58(2), 237-251.

Friends: Social Networking Sites for Engaged Library Services. Retrieved from $<\mathrm{http}$ //onlinesocialnetworks.blogspot.com/>.

Hair, J. F., R. E. Anderson, R. L. Tatham, \& W. C. Black. 1992. Multivariate data analysis with readings. New York: Macmillan.

Kim, K.-H., \& H. Yun. 2007. "Cying for me, Cying for us: Relational dialectics in a Korean social network site." Journal of ComputerMediated Communication, 13(1), article 15. Retrieved from
$<$ http://jcmc.indiana.edu/vol13/issue1/kim. yun.html>.

Li, C., \& J. Bernoff. 2008. Groundswell: winning in a world transformed by social technologies. Boston, MA: Harvard Business Press.

Lin, N. 2001. Social capital: A theory of social structure and action. Cambridge, UK: Cambridge University Press.

Lippert S. K., \& H. Forman. 2005. "Utilization of information technology: Examining cognitive and experiential factors of post-adoption behavior." IEEE Transactions on Engineering Management, 52(3), 363-381.

Lin, H.-F. 2007. "The role of online and offline features in sustaining virtual communities: An empirical study." Internet Research, 17(2), 119-138.

Marchionini, G., C. Plaisant, \& A. Komlodi. 1998. "Interfaces and tools for the library of congress national digital library program." Information Processing \& Management, 34(5), 535-555.

Moon, Y. J., \& J. H. Lee. 2006. "A study on the effect of trust of online community on community loyalty." Journal of the Korea E-Commerce Research Academy, 7(1), 3-22.

Nunnally, J. C. 1967. Psychometric theory. New York: McGraw-Hill.

Oh, D.-G. 2005. "Influences of public library service quality on user satisfaction and loyalty." Journal of the Korean Society for Information Management, 22(4), 61-78. 
Oleck, J. 2007. "Libraries use MySpace to attract teens: More and more libraries are taking advantage of the popular social networking site." School Library Journal, July, 16.

Parthasarathy, M., \& A. Bhattacherjee. 1998. "Understanding post-adoption behavior in the context of online services." Information Systems Research, 9(4), 362-379.

Piccoli, G., \& G. Ives. 2003. "Trust and the unintended effects of behavior control in virtual teams." MIS Quarterly, 27(3), 365-295.

Podsakoff, P. M., S. B. MacKenzie, J.-Y. Lee, \& N. P. Podsakoff. 2003. "Common method biases in behavioral research: A critical review of the literature and recommended remedies." Journal of Applied Psychology, 88(5), 879-903.

Ridings, C. M., \& D. Gefen. 2004. "Virtual community attraction: Why people hang out online." Journal of Computer-Mediated Communication, 10(1), article 4. Retrieved from.

$<\mathrm{http} / / /$ jcmc.indiana.edu/vol10/issuel/ridi ngs_gefen.html>.

Rogers, E. M. 2003. Diffusion of innovations. New York: Free Press.

Spiller, J., A. Vlasic, \& P. Yetton. 2007. "Postadoption behavior of users of Internet service providers." Information \& Management, 44(6), 513-523.

Tiwana, A., \& A. A. Bush. 2005. "Continuance in expertise-sharing networks: A social perspective." IEEE Transactions on Engineering Management, 52(1), 85-101.

Thong, J.Y.L., S.-J. Hong, \& K. Y. Tam. 2006. "The effects of post-adoption beliefs on the expectation-confirmation model for information technology continuance." International Journal of Human-Computer Studies, 64(9), 799-810.

University of Minnesota. 2008, June 21. Educational benefits of social networking sites uncovered. ScienceDaily. Retrieved July 16, 2008, from

$<\mathrm{http}: / /$ www.sciencedaily.com-/releases/2 008/06/080620133907.html>.

van Deventer M. J., \& R.M.M.M. Snyman. 2004. "Measuring for sustainability: A multidimensional measurement framework for library and information services." LIBRI, 54(1), 1-8.

Venkatesh, V., \& F. D. Davis. 2000. "A theoretical extension of the technology acceptance model: Four longitudinal field studies." Management Science, 46(2), 186-204.

Wenger, E., R. McDermott, \& W. M. Snyder. 2002. Cultivating communities of practice. Boston, MA: Harvard Business School Press.

Zeithaml, V. A., L. L. Berry, \& A. Parasuraman. 1996. "The behavioural consequences of service quality." Journal of Marketing, 60(2), 31-46. 


\section{〈Appendix I〉 First Round Factor Analysis Results}

\begin{tabular}{|c|c|c|c|c|c|c|}
\hline & Factor 1 & Factor 2 & Factor 3 & Factor 4 & Factor 5 & Factor 6 \\
\hline S1 & 0.84 & 0.11 & 0.10 & 0.13 & 0.20 & -0.04 \\
\hline S2 & 0.83 & 0.09 & 0.14 & 0.15 & 0.22 & -0.09 \\
\hline C3 & 0.77 & 0.10 & 0.08 & 0.14 & 0.03 & 0.34 \\
\hline S3 & 0.76 & 0.12 & 0.10 & 0.10 & 0.12 & -0.04 \\
\hline S4 & 0.74 & 0.11 & 0.23 & 0.12 & 0.22 & -0.10 \\
\hline $\mathrm{C} 4$ & 0.74 & 0.05 & 0.10 & 0.07 & 0.04 & 0.32 \\
\hline $\mathrm{C} 2$ & 0.66 & 0.03 & 0.05 & 0.23 & 0.05 & 0.21 \\
\hline $\mathrm{Cl}$ & $\underline{0.59}$ & 0.22 & 0.10 & 0.38 & 0.05 & 0.27 \\
\hline $\mathrm{R} 2$ & 0.14 & 0.90 & 0.09 & 0.18 & 0.07 & -0.01 \\
\hline R3 & 0.10 & 0.90 & 0.11 & 0.20 & 0.06 & 0.03 \\
\hline R1 & 0.12 & 0.85 & 0.12 & 0.17 & 0.12 & 0.07 \\
\hline $\mathrm{R} 4$ & 0.11 & 0.82 & 0.09 & 0.14 & 0.07 & 0.09 \\
\hline $\mathrm{R} 5$ & 0.09 & $\underline{0.49}$ & 0.37 & 0.14 & -0.01 & 0.27 \\
\hline P3 & 0.19 & $\overline{0.08}$ & 0.85 & 0.11 & 0.00 & 0.07 \\
\hline P5 & 0.12 & 0.08 & 0.81 & 0.10 & 0.10 & 0.03 \\
\hline P2 & 0.22 & 0.04 & 0.78 & 0.12 & 0.07 & 0.07 \\
\hline P1 & 0.05 & 0.15 & 0.72 & 0.16 & 0.08 & -0.03 \\
\hline $\mathrm{P} 4$ & 0.04 & 0.12 & 0.71 & 0.05 & 0.02 & 0.13 \\
\hline KQ5 & 0.19 & 0.14 & 0.10 & 0.81 & 0.09 & 0.02 \\
\hline KQ1 & 0.13 & 0.13 & 0.08 & 0.78 & 0.09 & 0.20 \\
\hline KQ4 & 0.16 & 0.19 & 0.14 & 0.74 & 0.14 & -0.06 \\
\hline KQ3 & 0.21 & 0.21 & 0.15 & 0.73 & 0.11 & 0.11 \\
\hline KQ2 & 0.13 & 0.12 & 0.14 & 0.67 & 0.13 & 0.09 \\
\hline $\mathrm{RC2}$ & 0.16 & 0.11 & 0.07 & 0.12 & 0.84 & 0.18 \\
\hline RC3 & 0.16 & 0.10 & 0.04 & 0.19 & 0.82 & 0.07 \\
\hline $\mathrm{RCl}$ & 0.27 & 0.04 & 0.10 & 0.15 & 0.76 & 0.10 \\
\hline $\mathrm{RC} 4$ & 0.16 & 0.11 & 0.15 & 0.14 & 0.20 & $\underline{0.76}$ \\
\hline RC5 & 0.24 & 0.15 & 0.13 & 0.16 & 0.39 & $\underline{0.56}$ \\
\hline Eigenvalues & 9.31 & 2.95 & 2.43 & 1.89 & 1.66 & 1.04 \\
\hline$\%$ of Variance & 33.26 & 10.54 & 8.69 & 6.74 & 5.93 & 3.70 \\
\hline Cumulative \% & 33.26 & 43.80 & 52.49 & 59.22 & 65.15 & 68.84 \\
\hline
\end{tabular}

Principal Component Analysis with Varimax Rotation. 


\section{〈Appendix II〉 Second Round Factor Analysis Results}

\begin{tabular}{c|c|c|c|c|c}
\hline & Factor 1 & Factor 2 & Factor 3 & Factor 4 & Factor 5 \\
\hline S1 & $\mathbf{0 . 8 4}$ & 0.10 & 0.08 & 0.13 & 0.15 \\
\hline S2 & $\mathbf{0 . 8 3}$ & 0.09 & 0.12 & 0.15 & 0.16 \\
\hline C4 & $\mathbf{0 . 7 9}$ & 0.12 & 0.10 & 0.16 & 0.09 \\
\hline S3 & $\mathbf{0 . 7 6}$ & 0.06 & 0.11 & 0.09 & 0.10 \\
\hline S4 & $\mathbf{0 . 7 6}$ & 0.12 & 0.09 & 0.10 & 0.07 \\
\hline C2 & $\mathbf{0 . 7 4}$ & 0.10 & 0.21 & 0.13 & 0.16 \\
\hline R2 & 0.66 & 0.02 & 0.06 & 0.23 & 0.10 \\
\hline R3 & 0.10 & $\mathbf{0 . 9 0}$ & 0.11 & 0.19 & 0.06 \\
\hline R1 & 0.12 & $\mathbf{0 . 9 0}$ & 0.12 & 0.21 & 0.06 \\
\hline R4 & 0.12 & $\mathbf{0 . 8 5}$ & 0.13 & 0.18 & 0.12 \\
\hline P3 & 0.21 & 0.06 & 0.10 & 0.15 & 0.07 \\
\hline P5 & 0.12 & 0.08 & $\mathbf{0 . 8 5}$ & 0.13 & -0.01 \\
\hline P2 & 0.22 & 0.04 & $\mathbf{0 . 8 1}$ & 0.10 & 0.10 \\
\hline P1 & 0.05 & 0.13 & $\mathbf{0 . 7 8}$ & 0.13 & 0.08 \\
\hline P4 & 0.05 & 0.12 & $\mathbf{0 . 7 2}$ & 0.16 & 0.06 \\
\hline KQ5 & 0.19 & 0.13 & 0.09 & 0.06 & 0.03 \\
\hline KQ1 & 0.14 & 0.13 & 0.09 & $\mathbf{0 . 8 1}$ & 0.07 \\
\hline KQ4 & 0.16 & 0.18 & 0.13 & $\mathbf{0 . 7 9}$ & 0.12 \\
\hline KQ3 & 0.22 & 0.21 & 0.14 & $\mathbf{0 . 7 4}$ & 0.11 \\
\hline KQ2 & 0.13 & 0.12 & 0.15 & $\mathbf{0 . 6 7}$ & 0.10 \\
\hline RC2 & 0.18 & 0.11 & 0.07 & 0.13 & $\mathbf{0 . 8 4}$ \\
\hline RC3 & 0.16 & 0.12 & 0.05 & 0.18 & $\mathbf{0 . 8 3}$ \\
\hline RC1 & 0.27 & 0.04 & 0.10 & 0.15 & $\mathbf{0 . 7 9}$ \\
\hline Vumulative \% & 8.09 & 2.81 & 2.41 & 1.84 & 1.56 \\
\hline Compalues & 33.71 & 11.72 & 10.03 & 7.66 & 6.49 \\
\hline & 33.71 & 45.42 & 55.46 & 63.11 & 69.60 \\
\hline & & & &
\end{tabular}

Principal Component Analysis with Varimax Rotation. 